DOI: $10.4274 /$ tjps. 03274

\title{
Investigation of Polyphenol Composition, Biological Activities and Detoxification Properties of Some Medicinal Mushrooms from Turkey
}

Naznoosh Shomali1, Okan Onar1, Tuğçe Alkan1, Nergiz Demirtaş2, Ilgaz Akata1, Özlem Yıldırım1

1Ankara University, Faculty Of Science, Department Of Biology, 06100 Tandogan, Ankara

2The Ministry Of Food, Agriculture And Livestock, Food Control Laboratory. Food Chemical Analysis Laboratory, Ankara

\begin{abstract}
Objectives: Ethanolic extracts of Ganoderma adsperum, Inonotus hispidus, Russula chloroides and Sarcodon imbricatus mushroom species were investigated for their polyphenolic contents and biological activities.

\section{Materials and Methods:}

The radical scavenging activity of the extracts were evaluated by using DPPH 2,2Diphenyl-1-(2,4,6-trinitrophenyl) method and their polyphenolic compounds were determined by HPLC analysis. Furthermore, the activity effects of mushroom extracts on the GST (glutathione-S-transferase) enzyme were also examined. Additionally, antimicrobial activity of mushroom extracts were evaluated with disc diffusion method.
\end{abstract}

\section{Results:}

Ethanolic extract of I. hispidus demonstrated the highest total phenolic content and total flavonoid contents with $227.23 \pm 4.96 \mathrm{mg}$ gallic acid equivalent/g and $42.14 \pm$ 0.20 quercetin equivalent/g values, respectively. The highest DPPH radical scavenging activity was also observed for ethanolic extracts of $I$. hispidus with 10.687 $\pm 1.643 \mu \mathrm{g} / \mathrm{mL} \quad \mathrm{IC}_{50}$ value. HPLC analysis demonstrated that $R$. Chloroides was comprised of ferulic acid, gallic acid and myricetin compounds. The highest GST enzyme activity effect was detected by the ethanol extracts of $I$. hispidus and S. 
imbricatus. None of the mushroom extracts demonstrated significant inhibition on the bacteria strains used.

\section{Conclusion:}

These results indicate that $I$. hispidus may be proposed as a new potential source of natural medicine and its potential may be related to its polyphenolic content, which needs further investigation.

Key words: Wild mushrooms, polyphenolic compounds, antioxidant, glutathione-Stransferase, detoxification properties

Abbreviations: DPPH, 2,2-Diphenyl-1-(2,4,6-trinitrophenyl); HPLC, highperformance liquid chromatography; GAE, gallic acid equivalent; GST, glutathione-Stransferase; QE, quercetin equivalent

\section{Öz}

Amaç: Ganoderma adsperum, Inonotus hispidus, Russula chloroides ve Sarcodon imbricatus mantar türlerinin etanolik özütleri, polifenolik içerikleri ve biyolojik aktiviteleri açısından araştırılmıştır.

Gereç ve Yöntemler: Ekstrelerin radikal süpürücü etkileri DPPH (2,2-Difenil-1-(2,4,6trinitrofenil) yöntemi kullanılarak ve polifenolik içerikleri HPLC analizleri ile belirlendi. Ayrıca, mantar ekstrelerinin GST (glutatiyon-S-transferaz) enzim aktivatör etkisi incelenmiştir. Bunlara ek olarak, mantar ekstrelerinin antimikrobiyal aktivitesi, disk difüzyon yöntemi ile değerlendirildi.

Bulgular:I. hispidus'un etanol ekstresi sırasıyla $227.23 \pm 4.96 \mathrm{mg}$ GAE/g ve $42.14 \pm$ $0.20 \mathrm{QE} / \mathrm{g}$ değerleri ile en yüksek toplam fenol ve toplam flavonoid içeriğini göstermiştir. DPPH radikalini en yüksek temizleme aktivitesi de I. hispidus'un etanol ekstresinde, $10.687 \pm 1.643 \mu \mathrm{g} / \mathrm{mL}$ IC $_{50}$ değeri ile gözlenmiştir. HPLC analizi, R. chloroides'in ferulik asit, gallik asit ve mirisetin bileşiklerinden oluştuğunu göstermiştir. En yüksek GST enzim aktivatör etki I. hispidus ve S. imbricatus'un etanol ekstrelerinde belirlenmiştir. Mantar ekstrelerinin hiçbiri kullanılan bakteri suşları üzerinde belirgin bir inhibisyon göstermemiştir. 
Sonuç: Bu sonuçlar, ileri araştırmalar gerektirip I. hispidus'un yeni bir potansiyel doğal ilaç kaynağı olabileceğini ve bu potansiyelin polifenolik içeriği ile ilişkili olabileceğini göstermektedir.

Anahtar kelimeler: Yabani mantarlar, polifenolik bileşikler, antioksidan, glutatyon-Stransferaz, detoksifikasyon özellikleri

Kısaltmalar: DPPH, 2,2-Difenil-1-(2,4,6-trinitrofenil); HPLC, yüksek performanslı sIVI kromatografisi; GAE, gallik asit eşdeğeri; GST, glutatyon-S-transferaz; QE, kuersetin eşdeğeri

\section{Introduction}

Recently, natural sources exploration for novel bioactive compounds has gained so much attention where it has helped to provide therapeutic drugs and principal compounds. Mushrooms traditionally known as the valuable source of natural bioactive compounds have been studied widely for their therapeutic capabilities. Medicinal mushrooms hereby have been proved to contain many biologically active compounds, and many effective drugs and agrochemical fungicides are derived due to secondary metabolites extracted and isolated from mushrooms. ${ }^{1-2}$ Some of the most recent isolated and identified compounds from the mushrooms have shown to promise antiviral, antibacterial, antioxidant, antidiabetic, immunomodulatory, antitumor and hepatoprotective properties. Moreover, they contain a number of valuable nutrients, including protein, enzymes, B vitamins (especially niacin), and vitamin D. ${ }^{3-4}$

Ganoderma adsperum is a species of Basidiomycetes. Several species of Ganoderma are rich in bioactive compounds such as triterpenoids and polysaccharides. Traditionally, the Ganoderma species have been 
widely used in the treatment of hepatopathy, chronic hepatitis, nephritis, hypertension, arthritis, neurastheine, insomnia, bronchitis, asthma and gastric ulcers. ${ }^{5}$ They were also investigated for a variety of potential therapeutic benefits such as reducing blood pressure, and blood cholesterol, antioxidant, anticancer, antidiabetic, antiviral, antibacterial properties. ${ }^{6-9}$ Wong et al. ${ }^{10}$ demonstrated that the extract of the G. lucidum which was prepared in hot water has a protective effect on cardiovascular system. This study suggests that it reduces superoxide-induced damage on heart. Additionally, Tel-Cayan et al. ${ }^{11}$ isolated applanoxidic acid G, applanoxidic acid E, applanoxidic acid $A$ and 22-stigmastenol compounds from $G$. adspersum and investigated antioxidant and anticholinesterase activities of the mushroom extracts and the isolated pure compounds. They reported that applanoxidic acid $\mathrm{E}$ and 22-stigmastenol showed significant antioxidant activities in the inhibition of lipid peroxidation. The same authors also demonstrated that applanoxidic acid $G$ and 22-stigmastenol compounds exhibited the moderate inhibiting activity against the butyrylcholinesterase enzyme (BChE).

Sarcodon imbricatus (Bankeraceae) is an edible mushroom. It is commonly known as the shingled hedgehog or scaly hedgehog. In folk medicine, it is used for lowering cholesterol level, relaxing muscles and arranging blood circulation. ${ }^{12}$ Many studies demonstrated that S. imbricatus is a good source of the sterol compounds. In the previous studies; ergosterol, ergostane and cholestane compounds have been isolated from S. imbricatus species. ${ }^{13-14}$ Particularly the presence of ergosterol peroxide in the methanol extract of $S$. imbricatus is important because it shows various biological activities, such as anti-leukemic, anti-cancer, apoptotic-inducing, and anti-inflammatory. ${ }^{15-17}$

Inonotus hispidus (Hymenochaetaceae) is commonly known as shaggy bracket. It is known as a pathogen on plants. However it has numerous medicinal properties. In previous studies, the antiviral activity of two phenolic compounds hispolon and hispidin which were isolated from the fruit bodies of $I$. hispidus were investigated. Obtained results show that hispidin and hispolon compounds exhibit considerable antiviral activity against influenza viruses type $A$ and $B .{ }^{18}$

Russula chloroides is a member of Russula genus, which belongs to Russulaceae family. Even though there is a high number of species, the biological properties of Russula have not been investigated well. 
Glutathione-S-transferase (GSTs) comprise of phase II metabolic isozyme family which exist in both eukaryotes and prokaryotes. These isozymes are best known with their ability to catalyze the conjugation of the reduced form of glutathione (GSH) to xenobiotic substrates for the purpose of detoxification. The eukaryotic species has multiple GST isozymes that are found in cytosol and membrane. They catalyze the process of glutathione conjugation in electrophilic regions using sulfhydryl group which increases solubility of xenobiotic and endogenous compounds. During this process, endogenous compounds like peroxidase lipids are detoxified together with the disintegration of compounds and xenobiotics. ${ }^{19-20}$

The main aims of this work are investigating the polyphenolic contents and biological activities of ethanol extracts of several wild mushrooms from local environment (G.adsperum, I.hispidus, R. chloroides and S. imbricatus). Furthermore, the GST enzyme activity of these mushroom extracts is evaluated for the first time.

\section{Materials and Methods}

\section{Chemical materials}

All chemicals used in the study were supplied from Sigma Aldrich (USA), except 2,4-dinitrochlorobenzene (CDNB), which was purchased from Gerbu (Germany), as well as nutrient broth, malt extract and malt extract agar which was provided from Merck (USA).

\section{Mushroom materials}

Mushroom samples of Ganoderma adsperum, Inonotus hispidus, Russula chloroides and Sarcodon imbricatus were collected from Istanbul-Belgrad Forest and Trabzon-Yomra regions. They were identified by Dr. Ilgaz Akata and they are being kept at the herbarium of Ankara University with Akata 6355, Akata 6052, Akata 5895 and Akata \& Yuzun 757 code numbers.

\section{Extraction of mushrooms}

For ethanol extraction, $10 \mathrm{gr}$ of dried samples were weighed and ground into a fine powder with liquid nitrogen, then mixed with $100 \mathrm{~mL}$ ethyl alcohol (96\%) at room 
temperature for $24 \mathrm{hr}$. The obtained extract, finally, was filtered using Whatman No. 1 paper. In the next step, the existing ethanol was removed using a rotary evaporator at $40^{\circ} \mathrm{C}$ and the remaining solution was lyophilized. Finally, the samples were then kept in dark and cold $\left(4^{\circ} \mathrm{C}\right)$ condition to prevent oxidative damage.$^{21}$

\section{Determination of total phenolic content}

The method of Folin Ciocalteu's was used to evaluate the content of total phenolic compounds of mushroom extracts. ${ }^{22}$ Each $0.1 \mathrm{~mL}$ of extract solution was mixed with $2 \mathrm{~mL}$ of a $2 \%(\mathrm{w} / \mathrm{v})$ sodium carbonate solution using a strong vortexing. After $5 \mathrm{~min}, 0.1 \mathrm{~mL}$ of $50 \%$ Folin-Ciocalteu's reagent (w/v) was added and vortexed, then incubated for $1 \mathrm{hr}$ at room temperature. Afterwards, the absorbance of each mixture was measured at $750 \mathrm{~nm}$ with UV-VIS spectrophotometer. Results were evaluated through using $0.05,0.1,0.15$ and $0.2 \mathrm{mg} / \mathrm{mL}$ of gallic acid (GA) as standard curve and recorded as milligrams (mg) GA equivalent/g of dried sample.

\section{Determination of total flavonoid content}

Aluminum chloride colorimetric method was utilized to determine the total content of flavonoids in samples. ${ }^{23}$ This test was conducted by mixing $0.1 \mathrm{~mL}$ of each extract solution with $0.15 \mathrm{~mL}$ of $95 \%$ ethanol, $0.01 \mathrm{~mL}$ of $10 \%$ aluminum chloride, $0.01 \mathrm{~mL}$ of $1 \mathrm{M}$ sodium acetate and $0.25 \mathrm{~mL}$ of dimethyl sulfoxide (DMSO). The mixture was then incubated at room temperature for $30 \mathrm{~min}$ and then the absorbance of the reaction was measured at $415 \mathrm{~nm}$ with UV-VIS spectrophotometer. Finally, the standard curve was produced using different concentrations of quercetin solutions $(0.025,0.05,0.1,0.15$ and $0.2 \mathrm{mg} / \mathrm{mL})$. The total flavonoid content of the extract was expressed as milligrams $(\mathrm{mg})$ quercetin equivalent $/ \mathrm{g}$ of dried sample.

\section{High performance liquid chromatography (HPLC) analysis}

The High Performance Liquid Chromatography (HPLC) assay was performed to investigate the phenolic compound profiles of ethanol mushroom extract. For this purpose, lyophilised sample was dissolved in the $2 \mathrm{~mL}$ of $80 \%$ methanol, then filtered using $0,45 \mu \mathrm{m}$ cellulose membrane filters before injection. Aliquots of $20 \mu \mathrm{L}$ were injected into the UPLC system (Shimadzu nexera×2, shımadzu corporatıon, Kyoto, 
Japan) equipped with a diode array detector (DAD) set at 280,320 and $360 \mathrm{~nm}$. A $250 \times 4.6 \mathrm{~mm}$ i.d., $5 \mu \mathrm{m}$, C18 ODS-3 column (intersil) was used. The mobile phase was composed of $\% 5$ formic acid $(A)$ and Methanol $(B)$, at flow rate of $0,9 \mathrm{~mL} / \mathrm{min}$. Elution gradient was $5-80 \%$ (B) from 0-60 min. Calibration curves for each phenolic standards (the best wavelength) were prepared for quantification. For this purpose, myricetin, quercetin hydrate, ferulic, gallic, vanillic, caffeic, chlorogenic and $p$ coumaric acids were used as positive controls. The HPLC analysis was carried out by the Central Laboratory of General Directorate of Food and Control Institute.

\section{Free radical scavenging activity by DPPH assay}

The radical scavenging activities of mushroom extracts were measured according to the methods of Sharma and Bhat ${ }^{24}$ with some modifications. The antioxidant activities of the extracts were determined on the basis of the radical scavenging effect of the DPPH-free radical. According to the procedure, $0.2 \mathrm{~mL}$ of mushroom extract at different concentrations were mixed with $0.5 \mathrm{~mL}$ DPPH ethanol solution $(0.12 \mathrm{mM})$ and $0.5 \mathrm{~mL}(96 \%)$ ethanol. Then samples were incubated for 30 $\mathrm{min}$ at room temperature and in darkness. Then absorbance was read at $517 \mathrm{~nm}$ by using UV-VIS spectrophotometer while gallic acid was employed as reference. The DPPH radical scavenging activity of each sample was expressed as the half maximal inhibitory concentration $\left(\mathrm{IC}_{50}\right)$ value and calculated from the dose-response inhibition curve.

\section{Isolation of cytosol from bovine liver}

The bovine liver used in this study, was provided by slaughterhouse of Kazan, Ankara, Turkey. The liver samples were homogenized in $10 \mathrm{mM}$ potassium phosphate buffer ( $\mathrm{pH} 7.0$ ), containing $0.15 \mathrm{M} \mathrm{KCl}, 1 \mathrm{mM}$ EDTA, and $1 \mathrm{mM}$ of DTT, using a glass Teflon homogenizer and then centrifuged at 10,000 X $g$ for $20 \mathrm{~min}$. The supernatant was filtered through cheesecloth and the filtrate was centrifuged at $30,000 \times \mathrm{g}$ for $60 \mathrm{~min}$. The collected supernatants were filtered again and the resultant filtrate was referred as cytosol. ${ }^{25}$ The prepared homogenates were kept in $80{ }^{\circ} \mathrm{C}$ for future analysis. Total protein content was determined by the Lowry method. ${ }^{26}$

\section{Testing activity of glutathione-S-transferase}


Glutathione-S-transferase (GSTs) activity was determined against the substrate, 1-chloro-2, 4-dinitrobenzene (CDNB), by monitoring the thioether formation at $340 \mathrm{~nm} .{ }^{27}$ In line with the protocol, the assay mixture composed of mushroom extract solutions (concentration in the range of $10-0.625 \mathrm{mg} / \mathrm{mL}$ ), $200 \mathrm{mM}$ potassium phosphate buffer ( $\mathrm{pH}$ 6.5) with $20 \mathrm{mM}$ CDNB and $50 \mathrm{mM} \mathrm{GSH}$ and bovine liver cytosolic fractions was prepared and used as the enzyme source to measure the GST activity. GSH-CDNB conjugate formation was followed in $1 \mathrm{~mL}$ total volume assay by using UV-VIS spectrophotometer at $340 \mathrm{~nm}$ for $2 \mathrm{~min}$. Initial rates of enzymatic reactions were determined as nanomoles of the conjugation product of GSH and reported as nmole/ minute/ $\mathrm{mL}$.

\section{Antimicrobial assay}

The antibacterial activities of mushroom extracts were determined against Gram (+) bacteria: Staphylococcus aureus ATCC 25923 and Gram (-) bacteria: Escherichia coli ATCC 25922, Pseudomonas aeruginosa ATCC 27853 strains using disc diffusion method. ${ }^{28}$ Bacterial strains were incubated at $37^{\circ} \mathrm{C}$ into the Nutrient Broth culture for 24 hours. Inoculants were prepared by transferring colonies of each organism into $0.9 \%$ sterile saline solution until the visible turbidity was equal to $0.5 \mathrm{McF}$ arland standard which contains approximately $10^{8} \mathrm{cfu} / \mathrm{ml}$ bacterial. Nutrient Agar was used as culture for antibacterial activities. Afterwards, $0.02 \mathrm{~mL}$ of each extract was applied on $6 \mathrm{~mm}$ diameter sterile paper discs (OXOID) and to eliminate any residual solvent, discs were left to dry overnight at room temperature. The surface of the plates was inoculated by using prepared inoculant containing saline suspension of microorganisms. Discs were placed in the center of the agar surface of each petri plate. Zones of inhibition were measured in $\mathrm{mm}$ after incubating petri plates at $30^{\circ} \mathrm{C}$ for $24 \mathrm{hr}$. For this study, streptomycin $(10 \mathrm{mg})$ and tetracycline $(30 \mathrm{mg})$ were used as positive controls for all samples.

\section{Results}

The ethanol extracts of Ganoderma adsperum, Inonotus hispidus, Russula chloroides and Sarcodon imbricatus were used to investigate their polyphenolic contents, antioxidant and antimicrobial activities. Also, for the first time, their effects on the GST activity were evaluated. With this research, each extract was prepared by dissolving $10 \mathrm{~g}$ of dry samples in $100 \mathrm{~mL}$ ethanol (96\%) solvent. The extraction yields 
of $G$. adsperum, I. hispidus, $R$. chloroides and S. imbricatus were in the range of 3.71 to $13 \%$. Also, total phenolic contents, total flavonoid contents and radical scavenging activity of the extract were determined using spectrophotometric assays. The percentage of the yields, total phenolic contents, total flavonoid contents and results of DPPH scavenging activity were shown in Table 1 . The total phenolic contents of extracts were observed to be between $227.23 \pm 4.96$ to $3.125 \pm 0.12 \mathrm{mg} \mathrm{GAE} / \mathrm{g}$ of the dry samples. Also, the total flavonoid contents varied from $42.14 \pm 0.20$ to $1.99 \pm$ $0.27 \mathrm{mg} \mathrm{QE} / \mathrm{g}$ of the dry samples. Phenolic and flavonoid contents of the ethanol extract of $I$. hispidus were calculated as $227.23 \pm 4.96 \mathrm{mg} \mathrm{GAE} / \mathrm{g}$ and $42.14 \pm 0.20$ $\mathrm{QE} / \mathrm{g}$, respectively and these are the highest values compared to other mushroom species. Free radical scavenging activity results were presented as percentage of DPPH radical scavenging activity of different extracts $(\mathrm{mg} / \mathrm{mL})$ according to concentration inhibition curves and $\mathrm{IC}_{50}$ values. The results showed that the highest amount of free radical scavenging activity was observed in the extracts of $G$. adspersum and $I$. hispidus with $48.002 \pm 0.861$ and $10.687 \pm 1.643 \mu \mathrm{g} / \mathrm{mL} \mathrm{IC} \mathrm{I}_{50}$, respectively (Figure 1 and Table 1). IC 50 value for gallic acid solution which was used as a reference was measured as $4.000 \pm 0.002 \mu \mathrm{g} / \mathrm{mL}$.

The phenolic profiles of the ethanol extracts from $G$. adsperum, I. hispidus, $R$. chloroides and S. imbricatus were studied by HPLC assay. In this assay; myricetin, quercetin hydrate, ferulic, gallic, vanillic, caffeic, chlorogenic and $p$-coumaric acids were used as reference. According to these results, $R$. chloroides included ferulic acid, gallic acid and myricetin compounds with 4.6020 $\pm 0.23,0.3027 \pm 0.02$ and $1.7460 \pm 0.09 \mathrm{mg} / \mathrm{g}$ values, respectively. Also, myricetin was found in all of the ethanol extract solutions. However, none of the extract solutions contained vanillic, caffeic, chlorogenic and $p$-coumaric acids. The results are demonstrated in Table 2.

With this study, it was shown that the G. adsperum, I. hispidus, R. chloroides and S. imbricatus extracts had effects on the GST enzyme activity. The extract were used within the range of $0.625-10 \mathrm{mg} / \mathrm{mL}$ concentration while measuring the activity on GST. The best activity profile for GST was observed with the crude ethanol extracts of $I$. hispidus and S. imbricatus (Fig. 2). The activities of the ethanol extracts of mushrooms were presented in Fig 2.

Moreover, we also demonstrated the antimicrobial activity of G. adsperum, I. hispidus, R. chloroides and S. imbricatus extracts against the S. aureus, E. coli and $P$. aeruginosa strains by disc diffusion assay. However, in comparison with the 
positive controls, none of the mushroom extracts had shown significant inhibitory effects on the bacteria strains. Results of disc diffusion assay of mushroom extracts are presented in Table 3.

\section{Discussion}

In this study, we found that the ethanol extract of $G$. adspersum contained significant amounts of phenolic and flavonoid compounds. It was also shown that $G$. adspersum extract exhibited significant free radical scavenging effect. Moreover, the ethanol extract from $G$. adspersum included remarkable amount of myricetin and quercetin hydrate compounds which have benefits on health. These compounds possess antioxidant and anticancer properties. ${ }^{29-31}$ It should be stated that $G$. adspersum extract revealed a weak antimicrobial activity against $S$. aureus, E. coli and $P$. aeruginosa strains. In the study of Nagaraj et al. ${ }^{32}$ evaluated the antioxidant activity of the methanol extracts of $G$. applanatum using in vitro models. They reported that high amount of phenolic and flavonoid compounds in the extract was determined and, therefore, the extract exhibited a significant antioxidant capacity in DPPH radical scavenging assay.

Furthermore, we demonstrated that the ethanol extract from S. imbricatus included a small amount of phenolic and flavonoid compounds, therefore, it showed lower antioxidant and antimicrobial activity profiles. Using HPLC assay we found that the ethanol extract of $S$. imbricatus also included gallic acid and myricetin compounds. It was highly effective on the GST activity in all doses. Marcotullio et al. ${ }^{33}$ reported that the methanol extract of $S$. imbricatus contained high amount of polyphenol contents, where it can justify the radical scavenging activity.

In this study it was found that the ethanol extract of I. hispidus contained high amount of phenolic and flavonoid contents which suggests that high potential effects of free radical scavenging activity may be raised due to the large amount of polyphenolic profiles. The low dosage of $I$. hispidus extracts showed an elevated effect on the GST activity. The ethanol extract of I. hispidus also demonstrated a slight antimicrobial effects on the bacteria strains. In another study, the inhibitory effect of phenolic compounds and alkaloids of I. hispidus was investigated on the lipase of Candida rugosa. ${ }^{34}$ It was observed that the phenolic and the alkaloid extracts were efficient inhibitors of the lipase of $C$. rugosa. Therefore, it was suggested that these compounds could be used in the treatment of candidiasis. 
Obtained results also indicated that the phenolic extracts shown a stronger radical scavenging activity than the alkaloids extracts. ${ }^{34}$

In our study, R. chloroides included very low amount of polyphenolic contents, and showed antioxidant and antimicrobial activities. On the other hand, HPLC analysis showed that the ethanol extract of $R$. chloroides contained remarkable amounts of ferulic acid, myricetin and gallic acid compounds. However, the effect of this extract on the GST enzyme activity was negligible.

\section{Conclusion}

In this research, biological activity and detoxification potential of the polyphenol contents which were isolated from Ganoderma adsperum, Inonotus hispidus, Russula chloroides and Sarcodon imbricatus species were investigated for the free radical scavenging and GST enzyme activities. It was found that the ethanol extract of $I$. hispidus had a large amount of phenolic and flavonoid contents. Also, it was observed that this ethanol extract had a high level of free radical scavenging potential. This activity may be attributed to the high concentration of polyphenol compounds in the ethanol extract of $I$. hispidus. Moreover, the ethanol extract of $I$. hispidus had a significant potential to increase the GST enzyme activity which plays a critical role on the detoxification pathways. Therefore, the I. hispidus has suggested to be a new potential source of natural medicine.

\section{Acknowledgements}

This work was financially supported by the Coordination of Scientific Research Projects of Ankara University (Research Project No: 16H0430011 and 15H0430001) in Turkey.

\section{References}

(1) De Silva DD, Rapior S, Sudarman E, Stadler M, Xu J, Alias SA, Hyde KD. Bioactive metabolites from macrofungi: ethnopharmacology, biological activities and chemistry. Fung Diver (2013) 62:1-40.

(2) Loria-Kohen V, Lourenco-Nogueira T, Espinosa-Salinas I, Marin FR, SolerRivas C, Ramirez de Molina A. Nutritional and functional properties of edible mushrooms: A food with promising health claims. J Pharm Nutr Sci (2014) 4: 187198. 
(3) Hansen MB, Jensen ML, Carstensen B. Causes of death among diabetic patients in Denmark. Diabetologia (2012) 55:294-302.

(4) Kozarski M, Klaus A, Jakovljevic D, Todorovic N, Vunduk J, Petrović P, Niksic M, Vrvic MM, Van Griensven L. Antioxidants of Edible Mushrooms. Molecules (2015) 20:19489-9525.

(5) Liu GT. Recent advances in research of pharmacology and clinical applications of Ganoderma (P. Korst.) species (Aphyllophoromycetideae) in china. IJ of Med Mushrooms. (1999) 1: 63-67.

(6) Smina TP, Mathewa J, Janardhanana KK, Devasagayam TPA. Antioxidant activity and toxicity profile of total triterpenes isolated from Ganoderma lucidum (Fr.) P. Karst occurring in South India. Envir toxic and pharma (2011) 32: 438-446.

(7) Vazirian M, Dianat S, Manayi A, Ziari R, Mousazadeh A, Habibi E, Saeidnia S, Amanzadeh Y. Anti-inflammatory effect, total polysaccharide, total phenolics content and antioxidant activity of the aqueous extract of three basidiomycetes. Res $\mathrm{J}$ of Pharma (2014) 1: 15-21.

(8) Rajoriya A, Tripathy SS, Gupta N. In vitro antioxidant activity of selected Ganoderma species found in Odisha, India. Trop plant research (2015) 2(2): 72-77.

(9) Ivone HA, Jorge MT, Guadalupe GRM, Berenice YJ. Total Polyphenols and Antioxidant Activity of Ganoderma Curtisii extracts. J of Med Plants Studies (2016) 4(4): $136-141$.

(10) Wong KL, Chao HH, Chan P, Chang LP, Liu CF. Antioxidant Activity of Ganoderma lucidum in Acute Ethanol-induced Heart Toxicity. Phyto Res (2004) 1024-1026.

(11) Tel-Cayan G, Ozturk M, Duru ME, Rehman MU, Adhikari A, Turkoglu A, Choudhary MI. Phytochemical investigation, antioxidant and anticholinesterase activities of Ganoderma adspersum. Indust Crops and Prod (2015) 76: 749-754.

(12) Kim SK. Method for making seasoned pork ribs by using Sarcodon aspratus and Acanthopanax senticosus broth for aging pork ribs. Patent, KR. (2006) 128485 A 20061214. 
(13) Ueno T, Yaoita Y, Kakuda R, Machida K, Kikuchi M. Studies on the constituents of mushrooms. VII. On the sterol constituents from the fruit bodies of Sarcodon aspratus. J of Tohoku Pharma Uni (1999) 46: 71-76.

(14) Huang Y, Dong Z, Liu J. Chemical constituents from the basidiocarp of Sarcodon aspratum. Yunnan Zhiwu Yanjiu (2002) 24(1): 125-128.

(15) Takei T, Yoshida M, Ohnishi-Kameyama M, Kobori M. Ergosterol peroxide, an apoptosis-inducing component isolated from Sarcodon aspratus (Berk.) S. Ito. Biosci, Biotech and Biochem (2005) 69(1): 212-215.

(16) Kobori M, Yoshida M, Ohnishi-Kameyama M, Takei T, Shinmoto H. 5,8Epidioxy-22E-ergosta-6,9(11),22-trien-3-ol from edible mushroom suppresses growth of HL60 leukemia and HT29 colon adenocarcinoma cells. Bio \& Pharma Bull (2006) 29(4): 755-759.

(17) Kobori M, Yoshida M, Ohnishi-Kameyama M, Shinmoto H. Ergosterol peroxide from an edible mushroom suppresses inflammatory responses in RAW264.7 macrophages and growth of HT29 colon adenocarcinoma cells. British J of Pharma (2007) 150 (2): 209-219.

(18) Awadh Ali NA, Mothanaa RAA, Lesnau A, Pilgrim H, Lindequist U. Antiviral activity of Inonotus hispidus. Fitoter (2003) 76: 483-485.

(19) Sheehan D, Meade G, Foley VM, Dowd CA. Structure, function and evolution of glutathione transferases: implications for classification of non-mammalian members of an ancient enzyme superfamily. Biochem J (2001) 360: 1-16.

(20) Nebert D, Vasiliou V. Analysis of the glutathione-S-transferase (GST) gene family. Human Genomıcs (2004) 1(6): 460-464.

(21) Onar O, Akata I, Celep GS, Yildirim O. Antioxidant Activity of Extracts from the Red-Belt Conk Medicinal Mushroom, Fomitopsis pinicola (Agaricomycetes), and Its Modulatory Effects on Antioxidant Enzymes. Int J Med Mushrooms (2016) 18(6): 501508.

(22) Slinkard K, Singleton VL. Total phenol analyses: Automation and comparison with manual methods. J Enol Viticul (1977) 28: 49-55. 
(23) Chang CC, Yang MH, Wen HM, Chern JC. Estimation of total flavonoid content in propolis by two complementary colorimetric methods. J Food Drug Anal (2002) 10(3):178-182.

(24) Sharma OP, Bhat TK. 2009. DPPH antioxidant assay revisited. Food Chem (2009) 113:1202-5.

(25) Shomali Moghaddam N, Isgor BS, Isgor YG, Geven F, Yildirim O. The Evaluation of Inhibitory Effects of Selected Plant Extracts on Antioxidant Enzymes. Fresenius Enviro Bull (2015) 4: 63-70.

(26) Lowry OH, Rosebrough NJ, Farr AL, Randall RJ. Protein measurement with the Folin phenol reagent. J Biol Chem (1951) 193(1): 265-75.

(27) Habig WH, Pabst MJ, Jakoby WB. Glutathione-S-transferases the first enzymatic step in mercapturic acid formaion. J Biol Chem (1974) 249: 7130-7139.

(28) Silici S, Koc AN. Comparative study of in vitro methods to analyse the antifungal activity of propolis against yeasts isolated from patients with superficial mycoses. Letters in Appl Micro (2006) 43: 318-324.

(29) Kandaswami C, Lee LT, Lee PP, Hwang JJ, Ke FC, Huang YT, Lee MT. 2005. The antitumor activities of flavonoids. In Vivo. (2005) 19(5):895-909.

(30) Chirumbolo S. The role of quercetin, flavonols and flavones in modulating inflammatory cell function. Inflamm Aller Drug Targets. (2010) 9(4):263-85.

(31) Yao $Y$, Lin G, Xie $Y$, Ma P, Li G, Meng Q, Wu T. Preformulation studies of myricetin: a natural antioxidant flavonoid. Pharmazie. (2014) 69(1):19-26.

(32) Nagaraj K, Malıkarjun N, Naıka RAJA, Venugopal TM. Antioxdative Activities of Wild Macro Fungı Ganoderma applanatum (PERS.) PAT. Asian J Pharm Clin Res (2014) 7(2): 166-171.

(33) Marcotullio MC, Oball-Mond Mwankie GN, Cossignani L, Tirillini B, Pagiotti R. Phytochemical analysis and antiradical properties of Sarcodon imbricatus (L.:Fr) Karsten. Natu Prod Commun (2008) 3(11): 1907-1910.

(34) Benarous K, Bombarda I, Iriepa I, Moraleda I, Gaetan H, Linani A, Tahri D, Sebaa M, Yousfi M. Harmaline and hispidin from Peganum harmala and Inonotus 
hispidus with binding affinity to Candida rugosa lipase: In silico and in vitro studies. Bio Chem (2015) 62: 1-7.

Table 1. The percent (\%) yield, total phenolics content, total flavonoid content and DPPH results of mushroom extracts

\begin{tabular}{|l|c|c|c|c|}
\hline \multicolumn{1}{|c|}{ Mushroom } & \begin{tabular}{c} 
Yield \\
\cline { 2 - 5 }
\end{tabular} & $\begin{array}{c}\text { TPC } \\
(\mathrm{mgGAE} / \mathrm{g})\end{array}$ & $\begin{array}{c}\text { TF } \\
(\mathrm{mg} \mathrm{QE} / \mathrm{g})\end{array}$ & $\begin{array}{c}\text { DPPH } \\
\text { IC } 50 \mu \mathrm{g} / \mathrm{mL}\end{array}$ \\
\hline I. hispidus & 3.71 & $227.23 \pm 4.96$ & $42.14 \pm 0.20$ & $10.687 \pm 1.643$ \\
\hline G. adspersum & 6.44 & $109.20 \pm 8.83$ & $13.6 \pm 0.22$ & $48.002 \pm 0.861$ \\
\hline S. imbricatus & 11.88 & $13.20 \pm 0.1$ & $5.45 \pm 0.11$ & $950.878 \pm 11.418$ \\
\hline R. chloroides & 13.00 & $3.125 \pm 0.12$ & $1.99 \pm 0.27$ & $2637.709 \pm 55.857$ \\
\hline Gallic acid & - & - & - & $4.000 \pm 0.002$ \\
\hline
\end{tabular}

Table 2. HPLC analysis of the phenolic profiles of mushrooms extracts

\begin{tabular}{|c|c|c|c|c|}
\hline Mushroom & I.hispidus & G.adspersum & S. imbricatus & R. chloroides \\
\hline
\end{tabular}




\begin{tabular}{|l|c|c|c|c|}
\hline & \multicolumn{4}{|c|}{ Content of Selected Polyphenol Compound mg/g } \\
\hline caffeic acid & - & - & - & - \\
\hline chlorogenic acid & - & - & - & - \\
\hline$p$-coumaric acid & - & - & - & $4.6020 \pm 0.23$ \\
\hline ferulic acid & - & - & - & $0,3027 \pm 0,02$ \\
\hline gallic acid & - & - & $0.7510 \pm 0.04$ & $1.7460 \pm 0,09$ \\
\hline myricetin & $0.6010 \pm 0.03$ & $0.6370 \pm 0.03$ & $2.8910 \pm 0.15$ & \\
\hline $\begin{array}{l}\text { quercetin } \\
\text { hydrate }\end{array}$ & - & $1.3040 \pm 0.07$ & - & - \\
\hline vanillic acid & - & - & - & \\
\hline
\end{tabular}

Table 3. Results of disc diffusion of mushroom extracts

\begin{tabular}{|l|c|c|c|}
\hline \multicolumn{1}{|c|}{ Mushroom } & $\begin{array}{c}\text { E.coli } \\
\text { ATCC 25922 }\end{array}$ & $\begin{array}{c}\text { S.aureus } \\
\text { ATCC 25923 }\end{array}$ & $\begin{array}{c}\text { P. aeruginosa } \\
\text { ATCC 27853 }\end{array}$ \\
\cline { 2 - 4 } & \multicolumn{3}{|c|}{ Inhibition zone (mm) } \\
\hline I.hispidus & 10 & 10 & 10 \\
\hline G.adspersum & 10 & 10 & 8 \\
\hline S. imbricatus & 9 & 9 & 8 \\
\hline R. chloroides & 8 & 8 & 15 \\
\hline Streptomycin & 20 & 23 & 20 \\
\hline Tetracycline & 13 & 35 & 9 \\
\hline
\end{tabular}


Fig. 1: Percent free radical scavenging activity of mushroom extracts. The data represent the mean $\pm S D(n=3)$.

Fig.2: Effects of mushroom extracts on GST enzyme activity (\%). The data represent the mean $\pm S D(n=3)$. 

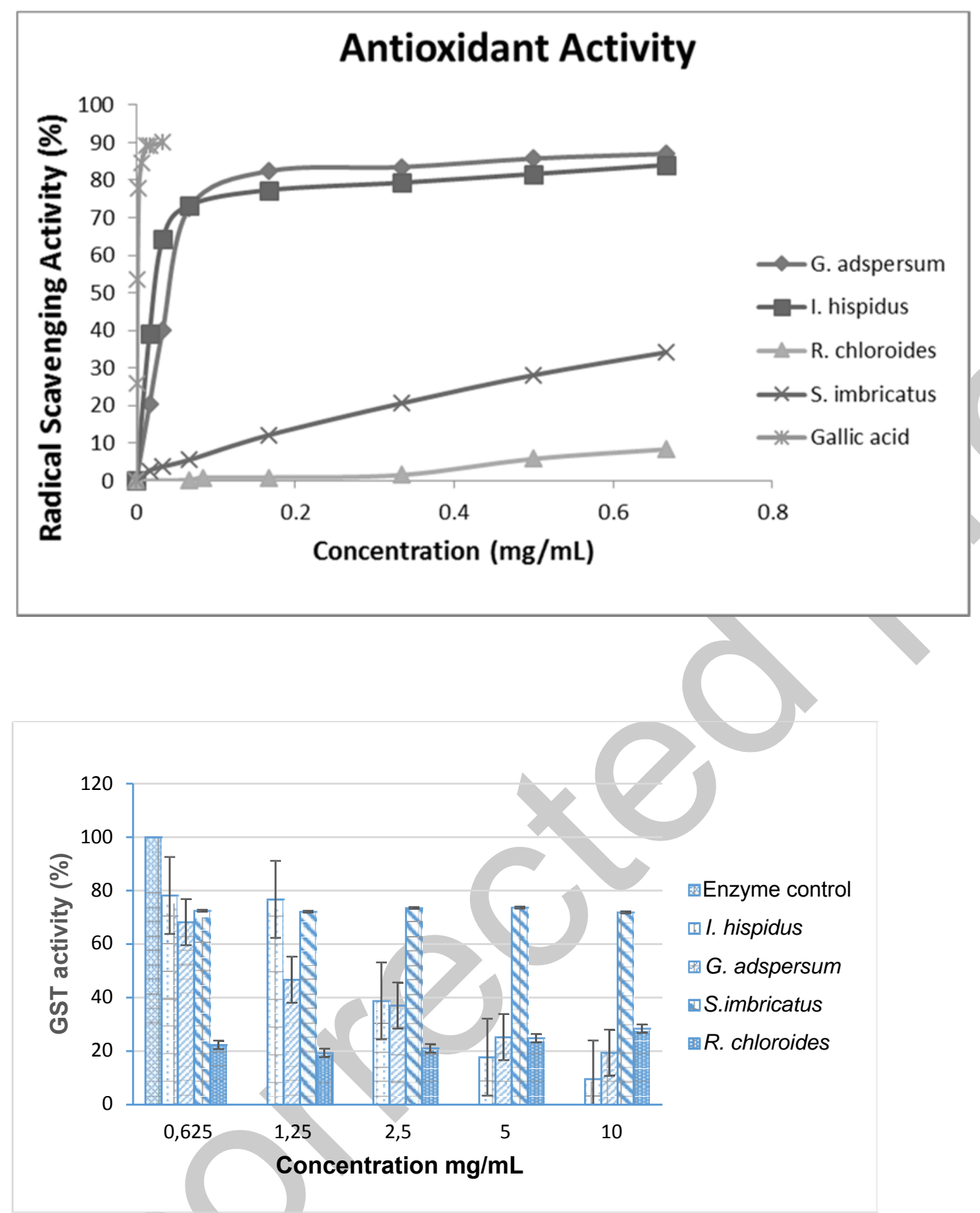